\title{
Caesarean section at Koudougou regional hospital centre: indications and prognosis
}

\author{
Nebnomyidboumbou Norbert Wenceslas Djiguemde ${ }^{1 *}$, Martin Lankaonde ${ }^{2}$, \\ B. Eveline Savadogo-Komboigo ${ }^{3}$, Sansan Rodrigue S. I. B. ${ }^{5}$, Wendlassida Estelle Ouedraogo ${ }^{4}$, \\ Blandine Thieba-Bonane ${ }^{3}$
}

\begin{abstract}
${ }^{1}$ Department of Obstetrics and Gynecology, ${ }^{2}$ Department of Intensive Care Anestheia, Koudougou Regional Hospital centre, Koudougou, Burkina Faso

${ }^{3}$ Department of Obstetrics and Gynecology, ${ }^{4}$ Department of Internal Medicine, Yalgado Ouedraogo University Hospital Center, Ouagadougou, Burkina Faso

${ }^{5}$ Department of Obstetrics and Gynecology, Regional University Hospital Centre Ouahigouya, Burkina Faso
\end{abstract}

Received: 01 October 2020

Accepted: 11 November 2020

\section{*Correspondence:}

Dr. Nebnomyidboumbou Norbert Wenceslas Djiguemde,

E-mail: norbertdjig@gmail.com

Copyright: ( ) the author(s), publisher and licensee Medip Academy. This is an open-access article distributed under the terms of the Creative Commons Attribution Non-Commercial License, which permits unrestricted non-commercial use, distribution, and reproduction in any medium, provided the original work is properly cited.

\section{ABSTRACT}

Background: Objective was to study the indications and the prognosis of cesarean section in the obstetrics and gynecology department of CHR Koudougou from August 1st to October $16^{\text {th }} 2018$.

Methods: This was a cross-sectional study for descriptive purposes with prospective collection of data over the month and monitoring of parturients up to the $42^{\text {nd }}$ day post caesarean section. The study covered the period from August 1 to October 16, 2018. Gestures received in the work room and those hospitalized for a scheduled cesarean were involved in this study.

Results: This study involved 316 deliveries. The caesarean section rate was $34.8 \%(n=110)$. The average age was 26.75 years with extremes of 12 and 42 years. Term pregnancies represented $90.9 \%$. History of cesarean section was observed in $47,3 \%$. The main groups contributing to the caesarean section rate represent: Groups 5 (9.5\%), Group 1 (9.2\%), Group $3(5.1 \%)$, the scar uterus $(17.3 \%)$ and suffering fetal $(14.6 \%)$. The reported complications were $15.5 \%$ including $3.6 \%$ parietal suppuration and $0.8 \%$ stillbirth.

Conclusions: The caesarean section occupies an important place in the maternity service of the RHC of Koudougou. Robson's group 5 was the largest contributor to the overall cesarean rate in our study. Measures should be taken in this group so that the uterine scar does not become an absolute indication for cesarean.

Keywords: Caesarean section, Indications, Koudougou regional hospital center, Prognosis

\section{INTRODUCTION}

The ideal caesarean section rate, according to the World Health Organization (WHO), is between $10 \%$ and $15 \% .^{1}$ Studies have shown that below a caesarean rate of $10 \%$ in the general population, maternal and neonatal mortality decreases if the caesarean rate increases. ${ }^{1}$ However, the priority is not to reach a specific rate but to make every effort to perform a caesarean section in all women who need it. $^{2}$ Given the risk of morbidity and mortality associated with caesareans, controlling caesarean rates is a major concern in the obstetric field. ${ }^{3}$ In Africa, national rates for caesarean sections remain at very low levels. In Zambia, the caesarean section rate increased from $1.9 \%$ in 1996 to $3 \%$ in $2007 .{ }^{4}$ In Kenya, the rate increased from $4 \%$ in 2003 to $6.2 \%$ in $2009 .{ }^{5}$ In Benin, from $2.2 \%$ in 1996, it increased to $3.6 \%$ in $2006 .^{6}$ In Uganda, the caesarean section rate $(3.1 \%)$ remained stable between 2000 and 2006. ${ }^{7,8}$ In Burkina Faso, the caesarean section rate increased from $0.7 \%$ in 2003 to $3.1 \%$ in $2010 .{ }^{9}$ No study 
has been conducted on the follow-up of women in postcaesarean section. The indications and prognosis of the caesarean section with follow-up of the caesarean patients up to the $42^{\text {nd }}$ day constitute the aim of the study.

\section{METHODS}

This was a descriptive cross-sectional study with data collection from August 1 to October 16, 2018 and followup of parturients until the 42nd day after cesarean section of all patients who have undergone a cesarean section. Patients caesarized outside the department, but referred for post-operative complications. The Robson classification is an international benchmark system for the assessment, monitoring, and comparison of cesarean rates in health care settings over time and between WHO recommended health care facilities. The groups of "Robson" are:

Group 1: Nulliparous, single pregnancy, cephalic presentation, gestational age $=37 \mathrm{SA}$, spontaneous labour.

Group 2: Nulliparous, single pregnancy, cephalic presentation, gestational age $=37 \mathrm{SA}$, induction of labour or prelabour caesarean section.

Group 3: Multiparous, single pregnancy, cephalic presentation, gestational age $=37 \mathrm{SA}$, spontaneous labour.

Group 4: Multiparous, no scarred uterus, single pregnancy, cephalic presentation, gestational age=37SA, induction of labour or prelabour caesarean section.

Group 5: All multiparous with at least one uterine scar, single pregnancy, cephalic presentation, gestational age $=37 \mathrm{SA}$.

Group 6: All nulliparous, single pregnancy, breech presentation.

Group 7: All multiparous, single pregnancy, breech presentation, including scarred uterus.

Group 8: All multiple pregnancies, including oblique scarred uterus included.

Group 9: All single pregnancies with transverse or oblique presentation, including scarred uterus.

Group 10: All single pregnancies with cephalic presentation, gestational age <37SA, including scarred uterus.

The epidemiological and clinical variables studied were: age, socio-professional status, spouse's profession, provenance, marital status, mode of admission, reasons for referral, medical history, gynecological and obstetric history, gestational age, number of fetuses, presentation of the fetus, emergency cesarean and scheduled cesarean, maternal and fetal prognosis and maternal and perinatal morbidity and mortality. The data was collected anonymously, captured and analyzed using Epi Info software version 3.5.2 in its English version and Excel 2016.

\section{RESULTS}

The caesarean rate was $34.8 \%$. That is to say 110 for 316 deliveries. The average age is $26.75 \pm 6.6$ years with extremes of 12 years and 42 years. The 25-29 year age group represented $32.7 \%$, the $30-34$ age group $16.4 \%$, the under 15 age group $1.9 \%$, the $15-19$ year age group $14.5 \%$, the 20 to 24 years $20 \%$ that of 34 to 39 years $10.9 \%$ ) and over 40 years $4.55 \%$. Housewives represented $63.6 \%$, pupils/students $10 \%$, civil servants $20 \%$ and shopkeepers $6.36 \%$. Women with a married life were represented at $80.6 \%$, singles $12.96 \%$ and those living with a partner $6.48 \%$. The population of our study living in urban areas was $58.2 \%$ and that living in rural areas $41.8 \%$.

Table 1: Distribution of women by reason for evacuation $(n=62)$.

\begin{tabular}{|c|c|c|}
\hline Reason for evacuation & $\begin{array}{l}\text { Number of } \\
\text { personnel }\end{array}$ & $\%$ \\
\hline $\begin{array}{l}\text { Term overrun on scarred } \\
\text { uterus }\end{array}$ & 3 & 4.8 \\
\hline Transverse & 4 & 6.5 \\
\hline Scarred uterus & 8 & 12.1 \\
\hline Working trial & 1 & 1.6 \\
\hline Stationary expansion & 1 & 1.6 \\
\hline Pre severe eclampsia & 4 & 6.5 \\
\hline Fetal distress & 5 & 8.1 \\
\hline Failure to commit & 2 & 3.2 \\
\hline Presentation of the front & 1 & 1.6 \\
\hline Calcified placenta & 1 & 1.6 \\
\hline $\begin{array}{l}\text { Uterine myoma on elderly } \\
\text { primiparous }\end{array}$ & 1 & 1.6 \\
\hline $\begin{array}{l}\text { Presentation of } \\
\text { headquarters }\end{array}$ & 4 & 6.5 \\
\hline $\begin{array}{l}\text { Heart sound fetuses not } \\
\text { perceived }\end{array}$ & 1 & 1.6 \\
\hline Bleeding & 1 & 1.6 \\
\hline $\begin{array}{l}\text { Cephalopelvic } \\
\text { disproportion }\end{array}$ & 5 & 8.1 \\
\hline Vaso-occlusive crises & 1 & 1.6 \\
\hline $\begin{array}{l}\text { Threat of premature } \\
\text { delivery }\end{array}$ & 1 & 1.6 \\
\hline Better support & 2 & 3.2 \\
\hline Mechanical dystocia & 1 & 1.6 \\
\hline $\begin{array}{l}\text { Premature rupture of } \\
\text { membranes }\end{array}$ & 4 & 6.5 \\
\hline Hydramnios & 1 & 1.6 \\
\hline Macrosomia & 2 & 3.2 \\
\hline $\begin{array}{l}\text { Excessive uterine height in } \\
\text { a primiparous woman }\end{array}$ & 5 & 8.1 \\
\hline Generally narrowed basin & 3 & 4.8 \\
\hline Total & 62 & 100 \\
\hline
\end{tabular}


Admission was direct in $46.4 \%$ of cases and evacuated patients represented $56.4 \%$ of cases. Table 1 presents the main reasons for the evacuation of caesarized women.

Three medical histories were found in women under caesarean section, including one (1) case of hypertension $(0.9 \%)$, one case of sickle cell disease $(0.9 \%)$, one case of HIV $(0.9 \%)$. The average number of pregnancies is $2.6 \pm 1.8$ with extremes of 1 and 11 pregnancies. The parity was between 0 and 10 with an average of $1.5 \pm 1.8$. Figure 1 illustrates the distribution of patients by number of pregnancies.

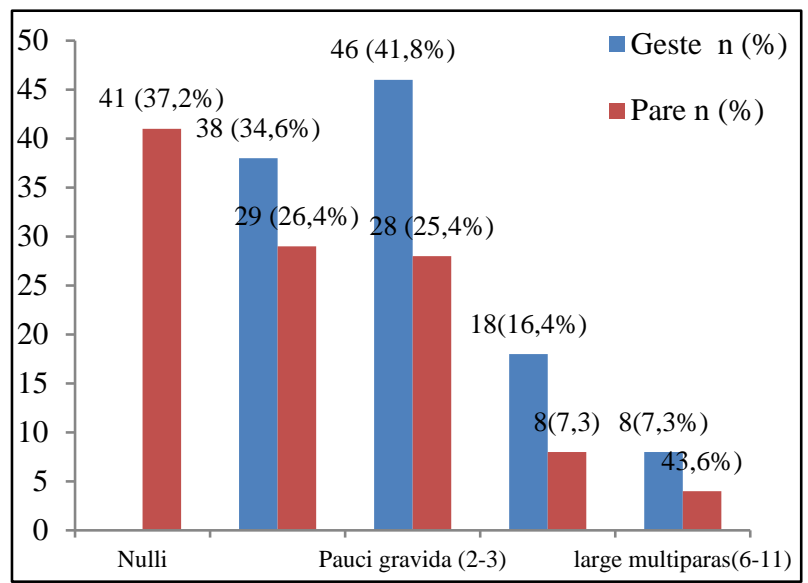

Figure 1: Distribution of women by number of gestures and pares $(n=110)$.

The distribution according to the number of scar is summarized in Figure 2.

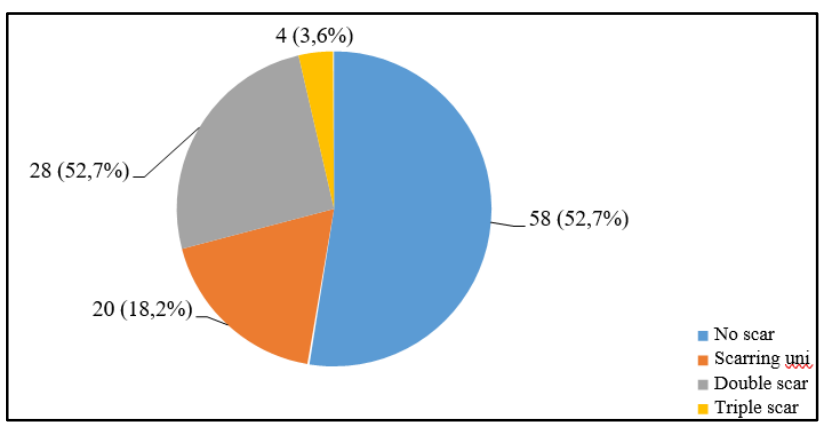

Figure 2: Distribution according to previous history of previous scarring.

A history of caesarean section was found in 52 women or $47.3 \%$. The gestational age was between 37 and 40 weeks of gestation or $90.9 \%$ of the cases. Figure 3 shows this distribution according to gestational age. The onset of labor was spontaneous (79.1\%), started (3.6\%) and $17.3 \%$ had a scheduled cesarean. Patients with a single pregnancy represented $86.4 \%$ (95 cases). Twelve pregnancies were 13 and 2 for triple pregnancies. The presentation of the fetus was cephalic in $88.2 \%$, the presentation of the seat $7.3 \%$ and the transverse presentation $4.6 \%$. Cesarean sections were performed urgently $(83.6 \%)$ and scheduled cesarean sections (16.4\%). Table 2 gives the distribution of cesareans by Robson's groups.

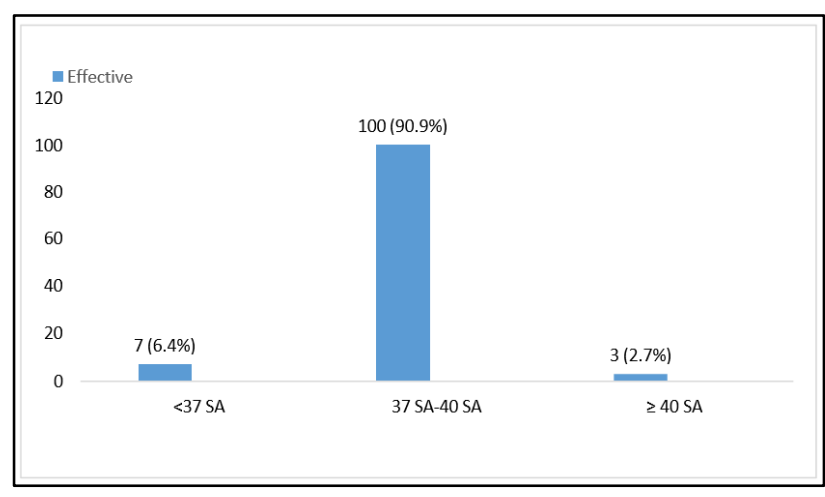

Figure 3: Distribution by gestational age at delivery $(n=110)$.

Table 2: Caesarean section rate according to Robson's groups $(n=110, n=316)$.

\begin{tabular}{|llll|}
\hline $\begin{array}{l}\text { Robson's } \\
\text { classification }\end{array}$ & $\begin{array}{l}\text { Size } \\
(\mathbf{A})\end{array}$ & $\begin{array}{l}\text { Percentage } \\
(\mathbf{A} / \mathbf{1 1 0})\end{array}$ & $\begin{array}{l}\text { Contribution } \\
\text { to overall C- } \\
\text { section rate } \\
(\mathbf{A} / \mathbf{3 1 6}))\end{array}$ \\
\hline Group 1 & 29 & 26.4 & 9.2 \\
\hline Group 2 & 3 & 2.7 & 0.1 \\
\hline Group 3 & 16 & 14.6 & 5.1 \\
\hline Group 4 & 4 & 3.6 & 1.3 \\
\hline Group 5 & 30 & 27.3 & 9.5 \\
\hline Group 6 & 5 & 4.6 & 1.2 \\
\hline Group 7 & 3 & 2.7 & 0.1 \\
\hline Group 8 & 10 & 9.1 & 3.2 \\
\hline Group 9 & 5 & 4.6 & 1.6 \\
\hline Group 10 & 5 & 4.6 & 1.6 \\
\hline Total & 110 & 100 & \\
\hline
\end{tabular}

We noted cases of anemia during hospitalization $(2.7 \%)$. All the patients operated on during our study came out alive. We noted no postoperative complications, i.e. $84.5 \%$ (93 cases) and 17 complications (15.4\%), including 15 complications among patients who were evacuated or referred, i.e. $13.6 \%$. All the caesarized women seen at the consultation of the $42^{\text {nd }}$ day, Figure 4 illustrates the distribution of complications.

Group 8 recorded $29.4 \%$ of cases of postoperative complications, followed by groups $3,4,5$ and 10 with $17.7 \%$ and $11.8 \%$ of cases respectively. The complaints at the postnatal consultation were: headache 3, 6\%, abdominal pain $1.8 \%$, pelvic pain $1.8 \%$, fever $0.9 \%$ and $91.8 \%$ presented no complaints. The mean length of stay was $3.2 \pm 1.18$ days with extremes of 2 and 10 days. During the study, 5 cases of fresh stillbirths or $3.9 \%$ of births were recorded, due to hypertensive problems (eclampsia, preeclampsia) and to the placenta previa. 
Table 3: Main indications for caesarean section in each Robson group.

\begin{tabular}{|c|c|c|c|c|c|c|c|c|c|c|c|}
\hline Main indications & G1 & G2 & G3 & G4 & G5 & G6 & G7 & G8 & G9 & G10 & Total \\
\hline Acute fetal suffering & 8 & --- & 6 & --- & 2 & --- & --- & --- & --- & --- & 16 \\
\hline Short inter-generic space & 4 & --- & 2 & 1 & 1 & --- & --- & --- & --- & 1 & 9 \\
\hline Immature pond & 2 & --- & --- & & 1 & --- & --- & --- & --- & 1 & 4 \\
\hline Placenta prævia covering & 2 & --- & --- & --- & 1 & --- & --- & --- & --- & --- & 3 \\
\hline $\begin{array}{l}\text { Fetopelvic disproportion for } \\
\text { hydrocephalus/macrosomia }\end{array}$ & --- & 2 & 1 & 1 & 2 & --- & --- & --- & --- & --- & 6 \\
\hline Unspecified fetopelvic disproportion & 4 & --- & 2 & --- & --- & --- & --- & --- & --- & --- & 6 \\
\hline Pre-uterine rupture & 3 & --- & 1 & --- & --- & --- & --- & --- & --- & --- & 4 \\
\hline Seat presentation & 1 & --- & --- & --- & --- & 5 & 1 & --- & --- & --- & 7 \\
\hline $\begin{array}{l}\text { Fetopelvic disproportion for } \\
\text { narrowed pelvis }\end{array}$ & 1 & --- & --- & --- & --- & --- & --- & --- & --- & --- & 1 \\
\hline Dynamic dystocia & 1 & --- & --- & --- & --- & --- & --- & --- & --- & --- & 1 \\
\hline $\begin{array}{l}\text { Antepartum haemorrhage for } \\
\text { retroplacental haematoma }\end{array}$ & 1 & --- & --- & --- & 1 & --- & --- & 1 & --- & --- & 3 \\
\hline Premature diaphragm rupture & 1 & --- & --- & --- & --- & --- & --- & --- & --- & --- & 1 \\
\hline Oligoamnios & 1 & --- & 1 & --- & --- & --- & --- & --- & --- & --- & 2 \\
\hline Eclampsia & --- & 1 & 1 & --- & & --- & ---- & --- & --- & --- & 2 \\
\hline Other obstetrical history ${ }^{(1)}$ & --- & --- & --- & 1 & 1 & --- & --- & --- & --- & --- & 2 \\
\hline Presentation of the recessed side & --- & --- & 1 & & --- & --- & --- & --- & --- & --- & 1 \\
\hline Medical pathology of the mother ${ }^{(2)}$ & --- & --- & 1 & 1 & 1 & --- & --- & --- & --- & --- & 3 \\
\hline $\begin{array}{l}\text { Previous caesarean section, scarred } \\
\text { uterus }\end{array}$ & --- & --- & --- & --- & 18 & --- & 1 & --- & --- & --- & 19 \\
\hline Pre-eclampsia & --- & --- & --- & --- & 2 & --- & --- & 1 & --- & 2 & 5 \\
\hline Uterine rupture & --- & --- & --- & --- & --- & --- & 1 & --- & --- & --- & 1 \\
\hline Multiple pregnancy & --- & --- & --- & -- & --- & --- & --- & 7 & --- & --- & 7 \\
\hline Transverse presentation & --- & --- & --- & --- & --- & --- & --- & 1 & 5 & --- & 6 \\
\hline Hydramnios & --- & --- & --- & --- & 1 & --- & --- & --- & --- & --- & 1 \\
\hline Total & 29 & 3 & 16 & 4 & 31 & 5 & 3 & 10 & 5 & 4 & 110 \\
\hline
\end{tabular}

1): Spontaneous abortions, 2) : Sickle cell disease, HIV, MTA

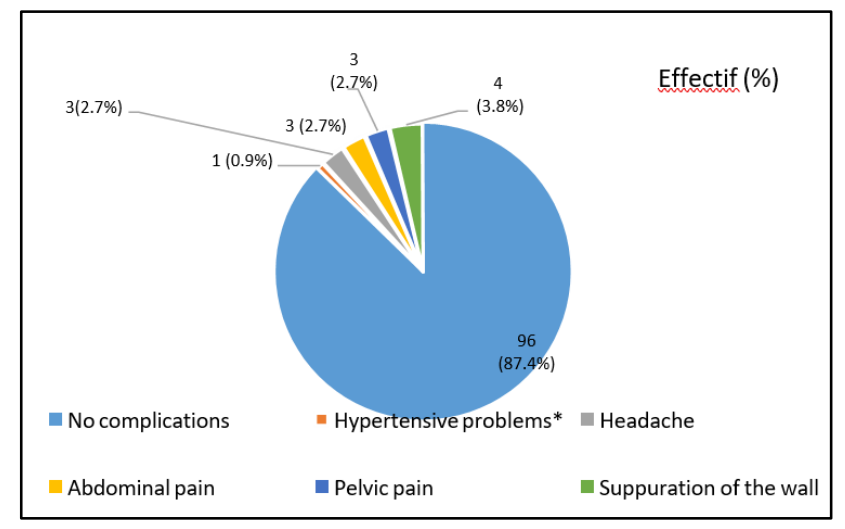

Figure 4: Distribution of complications in women with caesarean section at the 42 nd day visit

(*=hypertensive flare-up).

We identified 1 newborn baby who died within 24 hours of birth, i.e. $0.79 \%$ of the cases and 121 newborn babies who left alive, i.e $95.3 \%$, of which 3 were transferred to the pediatric unit for prematurity. The following Table presents the distribution of newborns according to the method of discharge from maternity.
Table 4: Distribution of newborns according to the mode of discharge from the maternity hospital.

\begin{tabular}{|c|c|c|c|}
\hline \multicolumn{2}{|c|}{ Children } & \multirow{2}{*}{$\begin{array}{l}\text { Numbers } \\
86\end{array}$} & \multirow{2}{*}{$\begin{array}{l}\text { Percentages } \\
67.7\end{array}$} \\
\hline \multirow{3}{*}{ Alive } & Mono-fetal & & \\
\hline & Twin & 26 & 20.5 \\
\hline & Triplet & 6 & 4.7 \\
\hline \multicolumn{2}{|c|}{ Stillborn fresh } & 5 & 3.9 \\
\hline \multicolumn{2}{|c|}{$\begin{array}{l}\text { Born alive and deceased } \\
<24 \text { hours }\end{array}$} & 1 & 0.8 \\
\hline \multicolumn{2}{|c|}{ Transfer } & 3 & 2.4 \\
\hline \multicolumn{2}{|c|}{ Alive on 42nd day } & 121 & 95.3 \\
\hline \multicolumn{2}{|c|}{ Total } & 127 & 100 \\
\hline
\end{tabular}

\section{DISCUSSION}

The frequency of cesarean section in this study was $34.8 \%$. This rate is close to that of Bokossa in Côte d'Ivoire in 2016 in $31.3 \% .^{10}$ Lower frequencies were found by Bambara in 2007, and Ouédraogo in Burkina Faso with respective rates of $11.3 \% ; 17.2 \%$ and $22.2 \% .6,11$ The frequency found in our study could be explained by the reference level of the CHR in the health pyramid in Burkina Faso. 
Table 5: Comparison of caesarean section rates and contributions to the overall rate by Robson's groups.

\begin{tabular}{|c|c|c|c|c|}
\hline \multirow[b]{2}{*}{$\begin{array}{l}\text { Groups of « } \\
\text { Robson » }\end{array}$} & \multicolumn{2}{|l|}{ Our series } & \multicolumn{2}{|c|}{ Ouédraogo CM Serie District of Boulmiougou } \\
\hline & Cesarean section rate $(\%)$ & $\begin{array}{l}\text { Overall rate } \\
(\%)\end{array}$ & Cesarean section rate $(\%)$ & $\begin{array}{l}\text { Overall rate } \\
(\%)\end{array}$ \\
\hline 1 & 26.4 & 9.2 & 17.4 & 5.1 \\
\hline 2 & 2.7 & 0.1 & 82.7 & 1.1 \\
\hline 3 & 14.6 & 5.1 & 10.9 & 4.3 \\
\hline 4 & 3.6 & 1.3 & 83.6 & 1.4 \\
\hline 5 & 27.3 & 9.5 & 49.8 & 5.8 \\
\hline 6 & 4.6 & 1.6 & 47.4 & 0.9 \\
\hline 7 & 2.7 & 0.1 & 23.9 & 0.7 \\
\hline 8 & 9.1 & 3.2 & 28.4 & 1.4 \\
\hline 9 & 4.5 & 1.6 & 93.1 & 0.7 \\
\hline 10 & 4.6 & 1.6 & 15.4 & 1.1 \\
\hline Total & 100 & 34.8 & 22.2 & 22.2 \\
\hline
\end{tabular}

The average age of women is 26.75 years and corroborates with the results of other authors. ${ }^{11}$ The 20 to 34 age group represented $69.1 \%$. This rate is close to certain authors. ${ }^{15}$ This could be explained by the high representativeness and the high fertility of this age group in the population of women of reproductive age. ${ }^{14}$

Patients from rural areas represented $41.8 \%$. Our results are higher than those of Ouédraogo in 2017 at the HDB which found $31.71 \% .{ }^{11}$ This difference could be explained by the reference level of the CHR in the health pyramid in Burkina Faso to provide secondary care.

The proportion of caesarean sections was higher among evacuated women $(56.4 \%)$ compared to those who came by herself $(43.6 \%)$ with $\mathrm{p}=0.9$. This could be explained by the fact that most of the evacuated women already presented a serious complication. Cesarean sections were performed in emergency $(83.6 \%)$ and $16.4 \%$ in the program.

Loco regional anesthesia was performed in $98.2 \%$ and $1.8 \%$ on GA. Table 5 compares the caesarean section rate and the rates according to the Robson groups in our study with those of other series performed at the BF.

The cesarean rate in Group 5 was $27.3 \%$ making it the largest contributor to the overall Cesarean rate of $9.5 \%$. Studies carried out in Burkina-Faso found similar results. ${ }^{11}$ Other studies around the world have had the same results. ${ }^{12-14}$ Our results are different from those of Nakamura Pereira and Al in Brazil for group 2 at the overall cesarean rate. ${ }^{15}$ The high rate of indications in group 5 could be explained by the high frequency of the indication for uterine scar in our study. Indeed, the uterine scar was the first indication for cesarean section with a proportion of $17.3 \%$ of all indications and the first in group 5 with a proportion of $58.1 \%$.

The second contributor to the overall cesarean rate is group 1 with a rate of $9.2 \%$. Our results are identical to those found Kazmi et al (Group 1=3.77\%) and Bilobrk et al (Group 1=3.74\%). ${ }^{12}$

Group 3 had a rate of $5.1 \%$. This rate corroborates that of Bilobrk et al (Group 3=1.42\%) who also found the same group. ${ }^{12}$ These contributions (group 1 and group 3 ) could be explained by the large number of these women in our study population and by the high frequency of SFA (14.6\%) among the indications for cesareans during our period of 'study. Groups 6, 7, 8, 9, 10 generally have very low rates. The particularity of group 9 , which contributes very little to the overall rate of caesarean section, is due to the low representability of this group in our study population (4.6\% of the population).

Postoperative complications were $15.5 \%$. This rate is lower than those reported in the African literature. ${ }^{17}$ The quality of care at CHR in Koudougou could explain the good maternal prognosis for operated patients.

The proportion of complications was significantly higher in evacuated parturients (13.6\%) compared to those who came by themselves $(1.8 \%)$ with a significant difference $(\mathrm{p}$ $=0.0033)$. This morbidity could be justified by the late evacuation and the unfavorable terrain on which the intervention is carried out (RPM, long working hours).

Robson's group 8 had the highest number of complications. Infectious complications were the most frequently encountered. Ouédraogo et al also found the same complication in the first rank with a percentage of 93.3\%. ${ }^{11}$ This could be explained by the fact that some patients were evacuated in time to first level hospital establishments (CHU) better suited to the management of complications.

In our study we noted 5 fresh stillbirths or $3.9 \%$ of births. This rate is lower than that of Bambara in 2007 which found a rate of $10.4 \%$ but higher than that of Ouédraogo with $3.4 \% .^{11,18}$ 
We recorded 1 case of death of newborns within 24 hours of life; this can only be explained by a delay in diagnosis because the CHR is equipped with a neonatology unit ready to receive newborns in vital distress.

The average length of hospital stay was $3.2 \pm 1.2$ days with extremes of 2 and 10 days. Our results are different from those of Ouédraogo who found average stays of 4.2 days respectively. Our results could be explained by the early lifting of patients who underwent a cesarean. ${ }^{11}$

\section{CONCLUSION}

Cesarean sections represent more than a third of deliveries in the gynecology-obstetrics department. The main indication for cesarean section was uterine scar (Robson group 5). Attention should also be paid to Groups 1, 2, 3 and 4 of Robson qualified as groups at low risk of cesarean section in our study. The indications for cesarean section must be limited to situations where the fetal or maternal prognosis is at stake in the very short term and must be defined beforehand. Neonatal mortality, as well as maternal morbidity are not negligible.

\section{Funding: No funding sources}

Conflict of interest: None declared

Ethical approval: The study was approved by the Institutional Ethics Committee

\section{REFERENCES}

1. World Health Organization (WHO), Caesarean section: an intervention to be done only in case of medical necessity. Available at https:// www.who.int/bulletin/volumes/98/1/19-236729/en/. Accessed on 10 August 2020.

2. World Health Organization (WHO). WHO statement on caesarean section rates. Available at https://www.who.int/reproductivehealth/publications /maternal_perinatal_health/cs-statement/en/.

Accessed on 12 September 2020.

3. Ray LC, Prunet C, Thauraux DC, Goffinet F, Blondel B. Robson's classification: a tool for evaluating Caesarean section practices in France. J Gynecol Obset Biol Reprod. 2015;44(7):605-13.

4. Central Statistical Office (CSO), Ministry of Health (MOH), Tropical Diseases Research Centre (TDRC), University of Zambia, and Macro International Inc. 2009. Zambia Demographic and Health Survey 2007. Calverton, Maryland, USA: CSO and Macro International Inc. 2009:311.

5. Kenya National Bureau of Statistics (KNBS) and ICF Macro. 2010. Kenya Demographic and Health Survey 2008-09. Calverton, Maryland: KNBS and ICF Macro. 2010:275.

6. National Institute of Statistics and Economic Analysis (INSAE) with the collaboration of National AIDS Control Program (PNLS) Cotonou, Benin and Macro International Inc. Calverton, Maryland, USA.
Available at https:// dhsprogram. com/pubs/ pdf/FR197/00PagesPréliminaires00.pdf. Accessed on 10 August 2020.

7. Uganda Bureau of Statistics (UBOS) and Macro International Inc. 2007. Uganda Demographic and Health Survey 2006. Calverton, Maryland, USA: UBOS and Macro International Inc. 2007;311.

8. Institut National de la Statistique et de la Démographie (INSD) and ORC Macro. 2004. Burkina Faso Demographic and Health Survey 2003.Calverton, MD, USA: INSD and ORC Macro. Available at https:// dhsprogram. com/ publications/ publication-fr256-dhs-final-reports.cfm. Accessed on 12 August 2020.

9. Institut National de la Statistique et de la Démographie (INSD) and ICF International, 2012. Enquête Démographique et de Santé et à Indicateurs Multiples du Burkina Faso 2010. Calverton, Maryland, USA: INSD and ICF International. Available at https:// dhsprogram. com/ pubs/ pdf/FR256/FR256.pdf. Accessed on 29 August 2020.

10. Bokossa M, Nguessan K, Doumbia Y, Kakou C, Djougou C, Boni S. Prophylactic and emergency Caesarean sections: about 394 cases at Cocody University Hospital (Abidjan). Med Afr Noire. 2008;55(11):594-601.

11. Ouédraogo CM, Ouédraogo A, Ouattara A, Lankoandé J. The practice of caesarean section in a district hospital in Ouagadougou epidemiological, clinical and prognostic aspects concerning 3,381 cases. Med Santé Trop. 2015;25:194-9.

12. Bilobrk JL, Dizdarevic SJ, Brkovic I. Analysis of cesarean section delivery at nova bila hospital according to the robson classification. Antropol Coll. 2015;39(1):145-50.

13. Kazmi T, Sarva SV, Saiseema V, Khan S. Analysis of caesarean section rate - according to Robson's 10 group classification. Oman Med J. 2012;27(5):415-7.

14. Kelly S, Sprague A, Fell DB, Murphy P, Aelicks N, Guo Y. Examining caesarean section rates in Canada using the robson classification system. J Obst Gynaecol Canada. 2013;35(3):206-14.

15. Pereira NM, Leal CM, Pereira EAP, Domingues RMSM, Torres JA, Dias MAB, Moreira ME. Use of Robson classification to assess cesarean section rate in Brazil: the role of source of payment for childbirth. Reproductive Health. 2016;13(3):128.

16. Foumane P, Mve KV, Njofang MJ, Ngantcha EA, Dohbit JS, Mboudou ET. Risk factors and prognosis of emergency caesarean sections at the gynaecoobstetric and paediatric hospital of Yaoundé (Cameroon) faculty of medicine and biomedical sciences, BP 4362. 2014;24(1):1.

17. Diallo FB, Diallo MS, Bangoura S, Diallo AB, Camara Y. Caesarean section: a factor in reducing fœto-maternal morbidity and mortality at the Ignace deen University Hospital Centre in Conakry (Guinea). Medicine Black Africa. 1998;45(6):359-64. 
18. Bambara M, Fougan E, Dao B, Ouattara S, Ouattara $\mathrm{H}$, Lankoandé J, et al. Caesarean section in an African environment: about 440 cases at the maternity hospital of the CHUSS of Bobo-Dioulasso (Burkina Faso). Med Afr Noire. 2007;54(6):344-8.
Cite this article as: Djiguemde NWN, Lankaonde M, Savadogo-Komboigo BE, Sansan RSIB, Ouedraogo WE, Thieba-Bonane B. Caesarean section at Koudougou regional hospital centre (RHC): indications and prognosis. Int J Reprod Contracept 